\title{
Urban Rituals in Sacred Landscapes
}

In this book, I have asked the question why autochthonous, local or regional sanctuaries were so vital to the development of poleis in Hellenistic Asia Minor even though they were located at great distances from the urban center. Although I have focused this research on a few case studies, the phenomenon was fairly common, as discussed in the introduction with the list of cities whose major sanctuaries were situated at a distance, sometimes even in faraway places (Table 1.1). In examining current approaches from archaeological and historical studies, it soon becomes apparent that available models are tailored to answer very different questions, regarding either the rural setting of urban sanctuaries in the context of Archaic and Classical Greece, or the degree of autonomy and economic, social or political dimensions of sanctuaries in Asia Minor. While both approaches have informed the framework of analysis applied here, they nonetheless leave a gap in interpreting the urban roles of major sanctuaries in the chora of poleis in Hellenistic Asia Minor, particularly regarding the dynamics of change that many of these local or regional shrines underwent as they were drawn into the orbit of the polis to become its primary sanctuary. The difference between the two main approaches lies not only in the nature of the disciplines of archaeology and history, but also in the different kinds of material or epigraphic data. I have attempted a synthesis, but have also noticed that the major studies in this area are largely informed by dualistic paradigms, with core-periphery, urban-rural, civilized-wild, and even Greek-non-Greek polarities that are more reflective of modern concerns than ancient realities. Since such biases will inevitably steer the results, I took a step back to look to other disciplines in order to gain a broader perspective on some of the fundamental issues at hand. Perceptions of space and landscape, ritual, cross-community contact, and identity are often taken at face value in studies of antiquity, yet are central concerns to the cognitive, social and spatial sciences. These disciplines help problematize these issues from very different angles, even if they require some tweaking before being applicable to the ancient world.

This current study incorporates relevant issues drawn from these various approaches that should be taken into account. The resulting framework of analysis, discussed in Chapter 2, provides a holistic tool that can help assess the multifarious contexts of sanctuaries in Asia Minor in the Hellenistic period. No two sanctuaries were alike, nor were their relationships with their

(C) CHRISTINA G. WILliAMSON, 2021 | DOI:10.1163/9789004461277_008

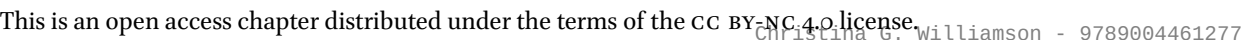


communities. But this tool allows for a deep assessment of the areas of change over time and their urban impact, as well as comparative analyses of different city-sanctuary relationships by pinpointing the most relevant areas of transformation and revealing larger patterns. With its focus on sources, the framework balances theoretical potential with empirical data; its fruitfulness has been demonstrated through the case studies. Before turning to the larger themes, it is worthwhile to briefly review the results, focusing on the role of landscape, major turning points in communal scope and their key interpretations.

This volume opened with a brief sketch of the landscape of Labraunda. Among timeless boulders near a strategic mountain pass and with a view that embraces much of southern Karia, this landscape of power was surely one of the main attractions for the Hekatomnids. They turned the old Karian sanctuary into a center of their domain, with the grand architecture and banqueting halls that framed the splendid views, and placed it within a defense network. This was Karia at its finest. It is no wonder that the polis of Mylasa laid claims to the shrine after the passing of the dynasty. Yet as it does so it shifted the focus of Labraunda from Karia to Mylasa. This marks an important second phase in the scope of the shrine, from encompassing the region (and dynasty) shrine under the Hekatomnids, to concentrating on the polis. This shift in focus met with opposition from the priests as the shrine became contested space. While the formal matter concerned administrative control over the extensive sacred lands, the real debate was who controlled the shrine and its deep heritage. The wealth of Labraunda lay in the layers of memory residing in its monuments, as well as its landscape and panorama that included Mylasa. Both priests and polis laid claims to the Hekatomnid past in their effort to legitimate control over the shrine and its landscape. The need by the democratic polis to engage the memory of the rulers whom they had once called 'tyrants' (I.Labraunda 41), can only be explained by the power of the past. The sanctuary was still visited by other Karian communities, but inscriptions of the Hellenistic era primarily concern political manifestations of the polis, and they mark key spots at the shrine. The city put itself on display here, before all of Karia, with the memory of the Hekatomnids as backdrop. Mylasa was a composite polis and the identity of the sub-groups was typically celebrated at their local shrines, yet Zeus Labraundos gave the polis a single face that it could present to the wider world by capitalizing on its Karian heritage.

The sanctuary of the Karian god Sinuri provides a rich contrast with Labraunda. Tucked away in a valley, the landscape of the sanctuary seems more connected with agriculture, yet the shrine nonetheless also drew the attention of the Hekatomnids. The main shift in scope here concerns the 
administration of the sanctuary, which passed from the Pelekos syngeneia in the late Classical period, who had direct relations with the ruling dynasty and appear to have been independent from Mylasa, to the Pormounos syngeneia. This group appears in the epigraphic record towards the end of the fourth century, and are clearly under the jurisdiction of Mylasa by the second century вс. The two main phases at the shrine of Sinuri are primarily distinguished by a lateral shift in the community using the sacred center. One might argue that in the Hellenistic period the sanctuary does not really qualify as urban space since its scope appears always to have focused on a subset, the syngeneia, rather than the entire body of citizens, and because its priesthood was hereditary, rather than being elected by a central body. Yet their rituals at the shrine clearly show that it functioned like urban space, reflecting civic structures, albeit on a smaller scale. The Pormounos syngeneia used the same Mylasan official jargon in their decrees - they followed the Mylasan calendar, adhered to its legal system, and adopted its institutions of financial administration and overall management of the sanctuary. They were among the most active subgroups of Mylasa in bestowing honors. They also constructed a stoa at the shrine that helped create an enclosed, urban-like space. Although we do not know whether they held processions across their landscape, their inscriptions highlight their sacred lands while their designated locations mark the key ritual spaces at the shrine. The nested levels of identity of the syngeneia would have been typical for most citizens of Mylasa, and probably several poleis in Karia or in Asia Minor for that matter. But their rituals especially show how a sanctuary offered a once-autonomous community a channel to assert its identity, while still being full members of the polis.

These were not the only sanctuaries in the sacred landscape of Mylasa. No doubt the picture would greatly be enhanced if we knew more about the sanctuary of Zeus Karios, or the identity of the god worshiped at Gencik Tepe. One of the most important cults for the polis was that of Zeus Osogollis, of which very little remains besides the inscriptions. ${ }^{1}$ These show nonetheless that it was the fulcrum of much of the religious and political life of Mylasa and formed thereby an important urban counterpart to the sanctuary of Zeus Labraundos. Finally, the pottery record from the Hellenistic period is notoriously difficult to identify - a finer chronological resolution would certainly enhance and challenge many of the interpretations postulated here. While such lacunas in our current knowledge must preclude any hard modeling, there is sufficient evidence to at least confirm that both of these distant country sanctuaries were

1 For a possible connection with the Uzunyuva area in Milas, Marek and Zingg (2018), 125-126. 
critical to the identity of Hellenistic Mylasa, albeit at different levels and for different reasons: Labraunda underwent a fundamental shift in concept as the polis, rather than the priests, assumed final control over the administration of the sanctuary and its assets, which contained besides cash crops the symbolic capital of the memory of the Hekatomnids; on a tighter scale, the syngeneia of Pormounos used the sanctuary of Sinuri to redefine itself as a community under the aegis of the polis and mirroring its institutions. Both show how the city and its surroundings adjusted to the polis model that was gaining momentum in the Hellenistic period.

Stratonikeia was similar in the disparate nature of its citizen base, yet its urban origins were more recent. Whereas Mylasa appears to have undergone an internal synoikism by the early fourth century under the Hekatomnids, the urbanization of Stratonikeia was a new development, having been founded as a Macedonian colony by the Seleukids in the second quarter of the third century BС. The surrounding communities would have merged gradually into the citizen base of the rising polis by the late third century вс. The sanctuary of Hekate at Lagina seems especially to have played a key role in unifying these communities. The shrine is located on a lush hillside near the conjunction of the Hayırlıdere valley and the north-south Marsyas valley. The steep mountains just north of this form a natural border and may well have been the northern limits of the chora of the new polis. The communal scope of the sanctuary underwent at least three phases: 1 ) when it belonged to the local polis of Koranza, in the late fourth and third century; to 2) when it became attached to Stratonikeia as a major urban sanctuary, in the third and second centuries, while Koranza became a deme of the polis; and finally, 3) when the festivals for Hekate and Rome were used to create political networks following the grant of asylia by Rome after the Mithridatic wars. Hekate's appearance on the early coinage attests to the strong bond with the polis in the second phase, as well as the radical transformation of her sanctuary into a large and monumental complex. But it is especially in this last phase that her sanctuary experienced a surge as inscribed urban space, with the many honorific decrees and dedications. Several concern the processions that integrated the diverse communities as the old road was now ritual space, carrying the urban body from the new town towards the sanctuary, but especially back into town, with the centripetal processions of the sacred key, the kleidos agoge. The cult of Hekate and its spectacles served to merge the composite citizen body and its dispersed territory into a unified polis, and later helped position the polis in the world of cities through its festival network. 
Forging a sense of community is a constant theme among these case studies, but is perhaps most evident at Panamara. Situated on a peak in the forested hills near the Marsyas valley south of Stratonikeia, the sanctuary was evidently at a strategic point as Philip V used it to garrison his troops. The scope of the cult of Zeus Karios underwent at least four phases: 1) in the late third and probably early second century BC, when it was administered by the koinon of the Panamareis, and attracted a regional following that extended well into the Rhodian peraia, and even across the Gulf of Keramos; 2) a transitional phase around the mid-second century $\mathrm{BC}$, when the sanctuary was still run by the koinon but with a priest from Stratonikeia, who revived the cult and expanded its network; 3) a period of stability under Stratonikeian control, probably when the cult of Hera was added; and 4) the period following the epiphany of Zeus during the attack by Labienus. This miracle had a galvanizing effect on the identity of the polis and became a common focus. It led to a grant of asylia by Rome and probably to the renewed expansion of cult network, initiated again by one of the priests. Panamara became a focus for urban ritual in a number of ways, with the entire population of Stratonikeia 'performing the landscape' through processions that emphasized male or female unity across the multiplicity of origins and social classes. Perhaps most spectacular was the procession that brought the festival and cult image of Zeus, now with the epithet of Panamaros, rather than Karios, into the center of town. The sanctuary clearly played a mediatory role in forging connections between Stratonikeia and the surrounding communities, creating a focus for the various strata of the polis, while extending its regional network.

The second century вС was a critical time for Stratonikeia, with two essential concerns: internal social cohesion, and territorial integrity. Both sanctuaries were critical in this regard. Drawing the two remote sanctuaries into orbit, and placing their gods at the heart of urban life was an act that bound the polis, sanctuary and landscape together in a locked relationship. Stratonikeia connected to the older communities north of town through the sanctuary of Hekate at Lagina; at the same time this gave it a strong presence in the area overlooking the Marsyas valley. Panamara was located in the hill country south of town, with a good view to the Marsyas valley as well, but also with its own ties to the communities in the southern Marçat mountains. Gaining control over this sanctuary was a major step for Stratonikeia in the direction of the Gulf of Keramos, and surely opened up new economic avenues of commerce for the landbound city. Both Lagina and Panamara were in their own ways determining factors in the territorial development of the polis in the Hellenistic period. 
The success of this is indicated by Strabo who, when giving a bird's eye view of Karia, states:

In the interior are three noteworthy cities: Mylasa, Stratonikeia, and Alabanda. The others are dependencies of these or else of the cities on the coast, among which are Amyzon, Herakleia, Euromos, and Chalketor. As for these, there is little to be said. ${ }^{2}$

Despite real territorial concerns and their likely locations near the edges of the Stratonikeian chora, Lagina and Panamara were nevertheless not true 'frontier' sanctuaries. There were many other issues at stake besides the definition of territorial borders. Strabo paints an image of Stratonikeia as a foreign 'Macedonian colony' dropped onto the landscape, which does not entirely seem to be the case. But unlike Mylasa it was a new polis developing in an environment that was already highly articulated socially, politically and religiously. The road to success lay in the integration of pre-existing communities in such a way that they could maintain their local identities while being incorporated into the larger citizen body of the polis. This was achieved not only by retaining their communities as the new demes of the polis, but especially by mobilizing a sacred center where their various backgrounds could coalesce into a common citizen identity. Lagina and later Panamara both provided excellent outlets where this could take place. Landscape clearly played a role but in a kind of inversion of Turner's theory - here urban communitas was being forged as the rituals at these country shrines served to produce and reinforce urban social structures. The difference is perhaps best articulated by the actions of the polis in inversing the rituals and bringing both cults into the urban center. ${ }^{3}$

Community-building, territorial ambition, and regional networking all must have been involved in Stratonikeia's choice to lay her identity in the gods of these two distant sanctuaries. But this could only take hold when the surrounding communities clearly understood that these gods, their sanctuaries, and the city were now inseparable. Coins, legends, inscriptions, architecture, and especially festivals and processions carried this message in overlapping layers, repeated over and over again until the pattern was simple and

2 Strabo 14.2.22 (transl. H.L. Jones (1929) The geography of Strabo, LCL 223): $\dot{\varepsilon} \nu$ $\dot{\varepsilon} \tau \hat{\eta} \mu \varepsilon \sigma o \gamma \alpha i \alpha_{\alpha}$

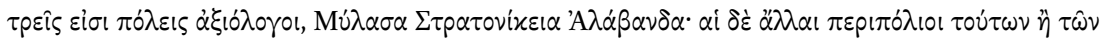

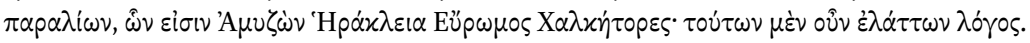

3 This is not quite the same as the formal sanctuary 'doublets' that Madeleine Jost observes in Arkadia, especially with the Lykaion in Megalopolis, but the motivation must have been similar; Jost (1994); also Kravaritou (2016) for the cult of Artemis Iolkia, that was brought to the center of Demetrias in Thessaly. 
commonplace. The sanctuaries thus acted as turning points for the perception of the landscape. By shifting the focus of the sacred landscape to the polis itself, Stratonikeia simultaneously realigned the political composition of this area along the Marsyas as well, with the polis at the logical center of both the physical and the cognitive environment.

The four case studies thus revolved around two cities, Mylasa and Stratonikeia, that were each seeking to define or redefine its position in the wake left by Alexander the Great. Country sanctuaries provided a muchneeded structuring principle - as economic centers, memory theaters, institutional organizations, spaces of geopolitical negotiation and social identity, but also eventually as magnets of urban pride.

\section{Frontier Sanctuaries?}

One of the criteria for selecting these four case studies was their proximity to natural or geographical borders in order to test their potential as frontier sanctuaries. This model is a ready explanation for major 'extra-urban' sanctuaries with a strong urban dimension in the Archaic Greek world. It could also easily be applied to these sanctuaries when considering their acquired urban status in connection with their location on the map. Labraunda, for example, is in a heavily fortified area along a mountain pass between Mylasa and Alinda to the north, and is nearly equidistant from these poleis. Mylasa is known to have aggressively pursued a course of expansion and the shrine of Zeus was clearly a critical concern to the polis; also, the fortress at the shrine was intensively used in the Hellenistic period, but whether this was by Mylasa or more probably by the strategos Olympichos is unclear. Also, Alinda hardly figures in the politics of Mylasa. From a territorial perspective, the sanctuary is much more likely to have been considered as a station at a critical point along the pass, rather than a frontier marker, although the festivals and fairs would certainly have given the road quite a bit of traffic, adding to the mediatory function of the shrine. For Mylasa, however, this border does not seem to have been a prime concern. One might have expected the eastern perimeter, near the shrine of Sinuri, to be a sensitive zone as neighboring Stratonikeia was also eager to expand where possible. Both of these assertive poleis were known to have had at least one border conflict (although the location is unclear). ${ }^{4}$ Looking at the map alone, the monumental sanctuary of Sinuri would seem a likely candidate for a frontier shrine. There are, however, two principal objections to this. One is that despite

4 I.Mylasa 134. 
the attention of the Hekatomnids, this shrine is more tucked away in a pocket rather than at a critical thoroughfare - in fact the terrain to the east becomes much more difficult to cross, although this may have been very different in antiquity. The second and more obvious factor is that, of all the shrines discussed in this volume, the shrine of Sinuri was the least concerned with urban politics. Although absorbed by Mylasa, it was not used to display any form of Mylasan identity other than through the sub-community to which it belonged. At the same time, as Mylasa expanded it seems to have left the sacred centers in its path alone, rather than converting them to 'polis' sanctuaries. This shows a different strategy than the colonies of Magna Graecia presumably followed.

As a colony, Stratonikeia might be a more plausible candidate for the frontier sanctuary model, with not one but two major shrines in the outer reaches of its territory. The sanctuary of Hekate at Lagina was located in a landscape becoming to the goddess of the crossroads. The conjunction of the Marsyas valley and the renown of her sanctuary would be one of the reasons that Strabo (14.2.29) lists Lagina, rather than Stratonikeia, among his few measuring points in Karia. The mountains to the north probably indicate the extent of Stratonikeian territory, but if so, the polis does not appear to have been preoccupied with it as such. It was, however, much more interested in the capacity of the shrine to establish links with communities, both within the territory as well as beyond its confines. Connectivity can be a property of frontier sanctuaries, and the festivals and later markets at Lagina would certainly have drawn crowds from afar, as they did at Labraunda. Yet this was more related to its capacity as network hub than as border mediator. With Panamara, however, borders could have played a more fundamental role in the absorption of the shrine by the polis. The hilltop shrine was presumably situated at the northern frontier of the Rhodian peraia in the early second century BC, and Stratonikeian interest in the cult may well have been related to territorial concerns as it exploited the mediatory role of the shrine. But it does not appear to have used the shrine to accentuate the border in any way. Moreover, by the first century BC the focus of the cult of Zeus at Panamara had clearly shifted inward to urban center, and its festivals were used to unite the disparate population of the polis.

None of the sanctuaries exhibit any signs of marking frontiers, despite their position near what was most likely a territorial boundary. Even their inherent mediatory function seems more related to connecting with other poleis and communities, rather than their immediate neighbors. Certainly these shrines came to signify the polis, but borders were only one of many functions that country sanctuaries could fulfill with regard to geography and civic territory. Labelling them as frontier shrines imposes political border issues that take 
us in the wrong direction with these sanctuaries, as charged as this term has become. The primary concerns of these two rising poleis in Hellenistic Asia Minor has already been shown to lie not at the border, but within. A recurring challenge that shines through each case study is internal social cohesion, and in most cases external connectivity. Both factors would have been a central matter as each city was faced with developing a strategy to position itself within the larger world of cities.

\section{Internal Social Cohesion - Building the Polis}

Dispersed communities were native to Karia, but the polis model was an imported concept, known principally along the coastal fringe. As the model took hold in Karia, cities were often created as agglomerations of much older communities. Mylasa incorporated a multiplicity of older clans with religious hearths and local identities of their own. As a Macedonian foundation, Stratonikeia drew its citizen base from the surrounding communities. The influx of 'Greek' and later 'Roman' citizens will have compounded matters in a way that was by no means limited to Karia. The challenge was to get this diverse and disparate group of people to identify with the idea of the polis together - this kind of coordination problem is exactly what ritual is equipped to deal with.

Ritual is a powerful instrument in creating a common focus, whatever that might be. Theories on the mechanisms of ritual help analyze its capacity as a coordinating mechanism through its focus in performance in space. This involves the mnemonic effect of ritual cognition, the element of spectacle or 'flashbulb memories', as well as the frequency of repetition and creation of ritual habit, regardless of content. Within the contexts of the cults in these case studies, however, the knowledge conveyed and reiterated through ritual is significant as well - the inseparable link between the god, the community, and its territory: this is particularly true at Lagina and Panamara, but also at Labraunda and even the sanctuary of Sinuri, albeit at a smaller scale.

Social cohesion as a conscious goal is particularly apparent at Stratonikeia. The ritual space at Lagina was built to literally embrace the community in a concentrated setting resembling an agora, while the rituals at Panamara aimed at men or women deliberately cut across all of the usual social boundaries, bringing the entire population together under this common denominator. Both cults also turned their gaze to the city, as the processions moved the sacred space and objects of the gods inwards towards the political center. This 
was an excellent means to create a common focus for a diverse, citizen base, with ritual and spectacle burning the shared experience into the minds of the participants, and inscriptions writing this memory into the minds of the community for generations to come.

Once autonomous communities were now subjugated to the polis as its demes and syngeneia. Mylasa seems to have had an even more federated political structure than Stratonikeia, as the hearth of identity continued to reside in the shrines of the clans - this is where honors were bestowed the most, with the shrine of Sinuri as an extreme example. The polis functioned almost as an abstract concept, a distributed model of cooperation as needed. This makes the polis-wide participation in the sanctuary of Zeus Labraundos all the more significant - here Mylasa is represented as a singular entity through the central institutions of the demos and the boule. This is also where international decrees and contracts or grants of proxeny were on display. Labraunda, with its renowned legacy and power of place, was understood to symbolize the polis, both by the Mylasans, but also by the international world of poleis. The sanctuary functioned as the outer face of Mylasa to the world.

Obviously, sanctuaries are all about creating community. Turner argued that this was a fundamental dynamic of distant sanctuaries, 'the center out there'. Yet in his view remote shrines foster an alternative community, an 'antistructure', that is distinct from urban or political identity, often even at odds with it. In this study, we have seen that it is precisely at such sanctuaries where urban identity, as polis religion, is promoted the most visibly. This study has elaborated on the dynamics involved in this in two significant ways. One is that the cults and festivals at these distant sanctuaries actively incorporated the landscape and space itself as part of the ritual focus. A sense of identity but also territorial integrity was constructed through ritual performance. The regular processions, the rituals at the sanctuaries and the memories recalled, and inscribed on the spot, helped configure social but also spatial memory. Such ritual acts and objects were vital towards creating a shared focus, common knowledge, and therefore a sense of unity. A second significant hallmark is that cities in Hellenistic Asia Minor could have a very local interpretation of what polis religion meant between the layers of their social composition. Communities continued to celebrate their older, indigenous identities through their own cult centers, while major shrines were used to shape the contours of evolving urban identity, both internally and externally. Having a central sanctuary for federated communities was in fact a very Karian solution to the problem of coordination, and in this regard the polis functioned as yet another level in the complexity of nested identities. This distinguished these cults from polis 
religion in the sense of classical Greece, where the polis presumably permeated every level of society.

Sanctuaries had an exceptional predisposition towards creating community, but especially their locations helped anchor a sense of polis identity and urban integrity, sealed through ritual. These ritual ties were a critical factor in establishing links with the wider network of communities.

\section{3}

\section{External Connectivity - Festival Networks}

These sanctuaries became involved in the public relations of the polis as it engaged with other poleis and communities. As centers of federated communities, this was a natural function of Karian shrines, but they could also connect communities together through less political ties of cult, such as syngeneia, kinship based on ancestral or mythical ties. The sanctuary of Zeus Karios at Panamara, for example, was held in common by Kallipolis, across the Gulf of Keramos, and the more local koina of the Londeis and the Laodikeis, as well as the Panamareis themselves. Connecting with these communities could have been a reason behind Stratonikeian involvement at Panamara in the first place. The role of such sanctuaries as hubs in a regional network seems to have been one of their main drawing features. Through endowments at the shrine, a polis could initiate a dialogue of goodwill with its communities. This is more apparent with the cults of Stratonikeia than of Mylasa, possibly due to the longestablished presence of Mylasa thanks to the Hekatomnids, while Stratonikeia still needed to legitimate its position. But it does explain in part the claims Mylasa laid on Labraunda. Thanks to their social capital, certain sanctuaries could provide a critical means for the polis to address the wider region at large. This pivotal function, however, was not restricted to major regional sanctuaries; it could also be leveraged at shrines with a more modest scope prior to their incorporation by the polis, as at Lagina. In this case, Stratonikeia used Hekate's festivals not only to coordinate local communities with a common focus, but also to mobilize Rome and the wider Greek world to acknowledge the authority and asylia of the shrine, and thereby the position of the polis. The contests of the festivals further served to promote the polis among the regional circuit of athletic competitions, especially in Karia and Ionia. Festivals, especially those celebrating an epiphany of the god, were important vehicles for poleis on the rise in building inter-urban networks.

Rational rituals, i.e. the means which the polis used to create a shared focus and thus generate common knowledge, worked equally well at this global level 
as it did at the local level of the polis. While the contests and honors allowed for distinction among individuals, as well as individual communities, the collective event helped to create a sense of global community, with the polis hosting the event at the ritual center of the festival, side by side with the deity which was being celebrated. This was a relevant message, and the place of cult in the territory of the polis served to foreground the sanctuary in the minds of the larger world as well, ensuring at the same time its relation with the polis. Besides these political goals, the general circulation of knowledge that traveled with the foreign delegates along the festival circuit surely helped increased the cosmopolitan standing of the polis, while raising awareness of its own place in the wider world.

With the natural function that these sanctuaries already possessed as connectors of communities at multiple levels, it would have been a small step to extend this to engage in the panhellenic trend that was sweeping across the Hellenistic world. ${ }^{5}$ This new tradition was well underway by the time of the Hekatesia-Romaia, although Stratonikeia was one of the earlier cities to involve Rome. By this time, deploying the inherent connectivity of such regional-turned-urban sanctuaries to put the polis on the world stage would have been a natural means to meet both local and geopolitical needs at once.

\section{$4 \quad$ Urban Identity}

The emphasis on social cohesion and internal and external networking indicate urban identity as a root cause for polis involvement at most of the sanctuaries discussed here. Criteria for this involvement with a sanctuary may be traced to aspects such as strategic location, visual region, position as hub in a nexus of communities, and the social and symbolic capital of the deity. All of these factors point to the ability of a cult to both capture and hold public attention while transforming the perception of civic territory at the same time controlling the cult meant controlling its sacred, social and political landscape.

The decisions taken at the polis level and the impact at these sanctuaries coincide well with the steps involved in building 'regional identity', in modern terms, as outlined by Paasi. ${ }^{6}$ He defines the following stages in this process as territorial shaping, symbolic shaping, institutionalism, and finally, establishment through external recognition. Considering the polis through this lens, with administrative, social, and territorial concerns, helps analyze how the

5 Chaniotis (1995); Parker (2004); van Nijf and Williamson (2016); see discussion in Chapter 2.

6 Paasi (2003) and especially (2009), discussed above in Chapter 2. 
different indicators of polis involvement at these sanctuaries coalesced in the construction of urban identity, and why they are especially apparent in poleis that were undergoing a momentous new phase in their development.

The first stage of territorial shaping matches the expansionist tendencies of the poleis discussed in the case studies. Borders were important, yet as we have seen there was much more to defining territory than just establishing its extent. Sanctuaries at sites perceived to be vital to the polis, such as a tactical location in the evolving political landscape, would logically have been 'tagged' for special treatment. The ability of a sanctuary to mobilize a local community or network of communities, discussed in the previous section, would also have been a positive factor for the polis. Another critical factor would have been the scope of a sanctuary's visual region, or viewshed, since this would have been added to the visual region of the polis itself. Of the case studies analyzed in this research, the sanctuaries that came to occupy a central position in the political scope of the polis were those that also possessed broad vistas. This may also explain why the sanctuary of Sinuri, although monumentalized by the Hekatomnids, was much less critical to Mylasa than Labraunda was; it looks out over its valley but not beyond. The sweeping panorama at Labraunda, on the other hand, was surely one of its primary assets - adding its visual region to that of Mylasa, located in the plain below, significantly expanded its visual and strategic reach. Similar observations were made above for the case studies concerning Stratonikeia; located in a narrow east-west valley, the strategic reach of the polis was greatly extended to the north and to the south with the inclusion of the visual regions of Lagina and Panamara. The significance of the sanctuaries helped foreground them in the minds of the local and regional communities, making them seem closer by. This was surely one of the reasons that modest sanctuaries were turned into 'big' places through architecture and their festivals pumped up as major spectacles, and especially why the processions were so crucial as they ensured the entire population physically 'performed the landscape' and inscribed it in their memory. Foregrounding these places in this way was even more effective in making them feel like they belonged to the polis than their legal status or position inside a border.

The second stage in building regional identity is that of symbolic shaping. Here too the sanctuaries, their deities and their festivals played a critical role in creating the shared focus that was necessary for a common identity. Foregrounding the sanctuaries in the minds of the citizens through processions and festivals also turned the landscape of the sanctuary itself into an emblem of the polis, becoming more and more familiar with each procession and each festival until it was naturally equated with the polis. The image of the god also became the icon of the city, especially on its coinage with its wider 
circulation. Mylasa's choice to depict Zeus Labraundos as a conscious echo of his image under the Hekatomnids illustrates the power of divine symbolic capital, especially in a form already familiar to the community while rerecalling its legendary past. The new image of Zeus Panamaros by Stratonikeia on its post-miracle coinage would have had a similar function; portraying Zeus as a rider-god broadcast the contemporary processions of the Panamareia while recalling his miraculous salvation of the polis. Adding epithets or changing them, as with Hekate Soteira and Zeus Panamaros, was also a clear statement in adaptation of cult focus to meet the needs of the polis, creating thereby a new identity for both.

The territorial and symbolic shaping of these sanctuaries were channeled through institutions, with decisions taken at a central level. While this is most evident in polis administration, in several cases a sanctuary was run by a local community. In this study, the syngeneia at Sinuri are seen to have functioned as a kind of polis in miniature. Also the koinon of the Panamareis at Panamara, or the katoikountes at the sanctuary at Lagina, were decision-taking bodies with institutions of their own. But these were not always understood in the same way across the board; a fundamentally different perception of priesthood and its chain of responsibilities seems to lie at the root of the conflict between Mylasa and the priests at Labraunda. The escalation of this is logical considering that the priesthood was one of the most important institutions in leveraging the resources of the sanctuary. This is evidenced by the priest Leon who advanced the link between Stratonikeia and Panamara. Priests were critical actors in tailoring the attention of the local gods to suit the rising polis. As leading figures in the rational rituals that bound polis and sanctuary together, shaping the memories of the citizens and the politics of the region, priests should certainly be seen as professional urban producers, or in Paasi's terms, as part of the cultural and media elite. ${ }^{7}$

Human relationships with the gods were always contingent on divine will. Shifting the focus of a sanctuary would only have been successful if the deity was perceived as principal actor, whose idea it was to take the developing polis under his or her wings. Whereas a complex process of negotiation likely took place, probably between the power brokers of the polis and the local elite at the sanctuary, for all involved it would ultimately have been the decision of the gods. An epiphany, a supernatural act of salvation on the part of the deity was the ultimate seal of godly approval for the polis. This was in turn a major reason to obtain the right of asylia, that could then be used to acquire local, regional, or international recognition, spark festivals and engage in geopolitics; hence

7 Paasi (2009), 132-133; Williamson (2013b). 
the surge in epiphanies in the later Hellenistic period. ${ }^{8}$ This is the final stage in the development of the identity of a region, i.e. polis: its establishment.

This study has demonstrated the importance of a close reading of the data in combination with an awareness of theoretical potential. It has shown the perils of applying models without considering the wider context, but also the necessity of providing alternative interpretations. While all of these sanctuaries were presumably located near frontiers, interpreting them based on this type of location alone will not get us very far. At the other end, a micro view of the epigraphic evidence will give us a story from the perspective of the polis, and a complicated one at that, but not a complete one. Solely empirical approaches will ultimately allow unconscious biases to enter if not tested against different options. In order to understand the evolving relationship between a sanctuary and a nearby urban center, a more holistic approach to the data is needed. Besides expanding the data set, this requires a wider range of theories to draw on in properly assessing the different data, while yielding a list of factors to consider. The framework of analysis applied in this study was developed with this aim in mind. It is now time to assess this framework, starting with the theories borrowed from other disciplines and how they were adapted to this study, and the overall value of this approach.

\section{$5 \quad$ Assessing the Theoretical Approaches}

In the review in Chapter 2, a gap was discerned in studies in the ancient world concerning major country sanctuaries. One the one hand, there is a strong and primarily archaeological focus on the Archaic and Classical Greek world, in which such shrines are largely seen as frontier sanctuaries, defending a sensitive border of a developing polis. On the other, in studies of Hellenistic Asia Minor sanctuaries are caught up in discussions of autonomy, based on economic and social status, or urban-rural bias, and largely based on epigraphy. Each tangent identifies significant facets that should be addressed in any assessment of the impact of urban centers on sacred landscapes, yet they also pursue a different line of inquiry than the present investigation. The difficulties of applying these models has been discussed at length above. In order to fill the gaps, I turned to other disciplines to better conceptualize the processes at work in the developing spatial and social relationships between local or regional sanctuaries and expanding poleis. These are discussed Chapter 2, but because these are 'new'

8 Platt (2011), 124-169. 
approaches to studies of antiquity it is worthwhile to further assess their value and future potential with regard to this kind of research.

\subsection{Visual Regionalization}

Theories on spatial memory are one of the foundations of this research. They show that mental snapshots and 'snippets' of spatial information are pieced together in our mind as 'cognitive collages', as Tversky calls them. ${ }^{9}$ Places appearing within the same 'snapshot' subconsciously feel like they are closer together, no matter what the actual distances in between might be. Ellard calls this effect 'chunking space', emphasizing how the brain zones places in a process of visual regionalization. ${ }^{10}$ Foregrounding spaces, as Hirsch emphasize, creates points of heightened awareness that further help compress space in the mind's eye. ${ }^{11}$ More than 'mental maps', these concepts better describe how spatial memory works and the importance of visual perception in creating mental associations and hierarchies among places.

In the context of this present research, the concept of visual region underscores the importance of viewsheds, or visibility from specific places, in the definition of civic territory. As observed above, combining the visual region of a sanctuary to that of the polis created a greater single unit that would coincide with physical territory. But how were such visual regions integrated? In this present research, ritual action was the key, such as processions that literally melded the visual regions together, but also the grand festivals that took place at the sanctuaries, creating indelible memories. This is what served to foreground these places, together with monumental architecture, literally heightening their visual and symbolic significance in collective memory. Visual regions were therefore especially critical to the territorial shaping of the polis, not only because they increased its strategic reach, but also for their symbolic value, by literally bringing the distant sanctuaries and their landscapes the edges of the territory within emotional reach, thus creating a broad sense of place and belonging that extended across the chora.

\subsection{Concentric and Linear Space}

Breaking space down into functional categories is also a mnemonic device that aids memories of places and how to navigate them. ${ }^{12}$ Two of these are 'nodes' and 'paths', elements that I have combined with the location and

\footnotetext{
9 Tversky (1993).

10 Ellard (2009), 126-128.

11 Hirsch (1995).

12 Lynch (1960).
} 
direction of communal focus in defining such spatial types as 'concentric', i.e. with a static central focus, or 'linear', i.e. with a progressive focus involving movement, whether physical or visual. Concentric space - enclosed spaces with a singular and internalizing focus - is characteristic of urban sanctuaries in the Hellenistic period, as it was of most urban spaces. ${ }^{13}$ It is concentric space in which monuments were typically erected, 'in the most conspicuous place', and it is this space which therefore best served as 'memory theater', an arena where past and present continuously flowed through each other in a web of associations that intermingled personal stories with collective memory. Urban sanctuaries were increasingly separated from the outer world by their delimiting architecture, becoming highly intense and focused spaces that were charged with intent and agency at multiple scales.

Linear space, on the other hand, is used to interpret how the sanctuary was integrated in the landscape and connected to places of significance, both physically and visually. The importance of visual linear space has already been stressed in several places as a tool that helps analyze ways that associations were created or emphasized through 'framing'. This should coincide with an analysis of the kinds of places that were visually ignored; although this was not pursued here, it could be relevant to other case studies as a way of addressing reception and resistance. Kinetic linear space refers to embodied movement through the landscape and in this context largely applies to sacred roads. This concept has helped understand the dynamics in processional routes that physically and ritually connected city and sanctuary. Two factors are involved in such routes: one is how they were determined, possibly involving environmental aspects (e.g. the 'shortest path' or 'least-cost corridors') as well as the need to wind it along places of significance; the other concerns the ability of such a route, once established, to attract places of meanings. Of the case studies discussed in this research, the two sacred roads that are known seem to be a combination of these factors. As places where the entire population regularly traveled up and down, they would have been magnets for social activity, accumulating meaning with the passage of time - evidence for this is found near the springs and by the many tombs that typically line the sacred roads near sanctuaries, just as they do around more urbanized areas. Future studies of this kind should search for other kinds, and often difficult to trace, of signs of presence en route.

13 Zimmermann (2009), 25; Emme (2013); Williamson (in press-c). 


\subsection{Rational Rituals}

The shapes of ritual space, concentric and linear, are related to rational rituals in that they provide either a static or a moving focus for the entire community. This visual focus occupies a central place in Chwe's theory on rational rituals as a coordinating device and one of the most direct means of generating common knowledge, a prerequisite for cooperation and social cohesion. ${ }^{14}$ Common knowledge is transmitted directly through joint attention towards a shared focus, which ritual readily provides. Cognitive studies on ritual have shown it to strengthen the neural pathways of memory, particularly through frequency, repetition, and spectacle, i.e. the 'flashbulb' memories. ${ }^{15}$ Of course, a shared focus is in itself not enough to create joint action, but it is a prerequisite according to rational ritual theory.

As straightforward as it seems, this theory has helped interpret a number of phenomena at the sanctuaries and in the cults with regard to the need of social cohesion, particularly in poleis that were made up of heterogeneous communities. Considering public rituals and ceremonies as rational rituals has led to insights into how ritual performance in festivals and processions worked to unite the population, not only by bringing them together in an enclosed space, but by giving them a shared focus embedded in ritual. That this did not automatically produce harmony or the desired effect is evident from the number of sacred laws that were established at various sanctuaries. But these were the exceptions that may prove at least the intention behind the rule.

In focusing on rational rituals as a means of 'saturation advertising' among humans, Chwe's theory purposefully leaves out the authority of the divine, or at least the perception of this authority. Although even this authority was not foolproof - e.g. oaths were often broken and sanctuaries were frequently sacked - it clearly brought the earnest of the rituals to a higher level by making them contingent on the pleasure of the divine will. ${ }^{16}$ The element of supreme power of the deity of the rituals in theory would certainly increase the compulsion to participate in them. This study does not presume that the rituals discussed here were consciously engineered or intended to be 'rational' - they were in the first place religious ceremonies. Nonetheless, understanding festivals and especially the processions as rational rituals makes the logic behind the sanctuaries, the cults, and ultimately the relationship with the polis much

\footnotetext{
14 Chwe (2001).

15 McCauley and Lawson (2002), 38-88, and (2007); Connerton (1989).

16 This is of course the paradox behind the grants of asylia, which enforce a human agreement to protect a sanctuary in recognition of the supreme power of its deity. Yet even this was a common focus, as it was used to attract the attention of peer poleis, as discussed above and in $\mathrm{Ma}(2003)$.
} 
more lucid as it leads to a better comprehension of the effects of ritual, especially by identifying the shared focus, or foci, at these festivals and interpreting the various ways in which it was produced.

\subsection{Network Model}

Network theory is gaining momentum in studies of the ancient world. ${ }^{17}$ One dimension of this concerns webs of associations, the general domain of Actor-Network Theory. ${ }^{18}$ In this study this has proved useful in understanding different levels of the past that can be evoked through architecture, providing another facet to the dimension of 'memory theater'. Network is certainly useful as an analogy to describe the role of sanctuaries as nuclei in a wider nexus of communities. Rigorous network analysis, however, would require a higher degree of data collection than this present book can accommodate as well as a greater consistency of data quality in order to study the weights of nodes and how strong or weak their ties were. But such studies are being conducted..$^{19}$ Future approaches could include agent-based modeling, where computer simulations can help elucidate patterns from incomplete data sets. In this present study, however, even a metaphorical application of network theory has proven fruitful. The information gathered here shows that three of the sanctuaries clearly functioned as a connecting factor between communities, while the larger (ego-)network aspirations of one of these, Lagina, can be traced with a fair degree of accuracy. ${ }^{20}$

Ma's application of the 'peer polity interaction' model has furthermore elucidated the basis of these ties, and how the wider community of poleis was typically founded on the inter-urban recognition of grants of asylia (inviolability) and claims of syngeneia (kinship). ${ }^{21}$ Both terms could be used to draw communities to a sanctuary, as at Lagina and Panamara respectively, and are flags of network activity, as with the other items on Ma's list, the theoria (foreign delegates), and the foreign judges who settled disputes. These two categories are less prevalent at the sanctuaries in the case studies in this research, but should be on the list of things to watch for in discerning the wider interests

17 Horden and Purcell (2000), 457. The Connected Past consortium is particularly active in promoting network analyses in historical and archaeological studies, see connected past.net.

18 Latour (2005); Guggenheim (2009).

19 See the Connected Contests project at the University of Groningen: connectedcontests. org for data on festivals and contestants, used to perform network analysis of inter-civic or panhellenic festival culture.

$20 \quad$ Van Nijf and Williamson (2016).

21 Ma (2003). 
of a polis in a particular sanctuary. Ma's list should furthermore be expanded to include new panhellenic festivals, e.g. the rise of quadrennial festivals, as well as inter-state treaties, such as isopoliteia or sympoliteia, which were often sealed by oaths in a sanctuary of relevance. ${ }^{22}$ Also, the role of rulers in initiating some of these festivals, or festivals initiated by cities in connection with ruler cult, deserves to be addressed from a network perspective, even though Ma excluded this from his equation. In short, network theory is certainly a way forward in considering how ritual served to create ties among cities and as a way for new cities to enter the geopolitical playing field, integrating them into the age-old model of Greek festival culture, but with a new twist that reinforced inter-urban bonds and goodwill with superpowers in the turbulent Hellenistic era.

\subsection{Regional Identity}

Regional identity, as modeled by Paasi, ${ }^{23}$ has already been extensively discussed above as well as in the case studies. This model has proven to be extremely useful in examining how sanctuaries were used to build and establish urban identity. When considering the ancient city-state as a region, then all of the stages which Paasi describes - territorial and symbolic shaping, institutionalism, and establishment through external recognition - remarkably fall into place: the overlap between ritualized landscape and civic territory, a central cult focus, the institutionalization of the priesthood, and the role of priests as urban leaders, and the use of the sanctuary for inter-urban networking. At the same time, Paasi's categories are broad enough to accommodate many of the theories and models previously mentioned. Because of this, very few issues were encountered in transferring the characteristics of this modern concept of 'regional identity' to 'polis identity' in the ancient Greek world.

Nonetheless, based as it is on modern political and geographical studies, a few minor technical modifications were needed. This concerns in the first place the importance of three-dimensional features in the landscape as experienced, e.g. mountains, rivers, and foregrounded places, rather than cartographic outlines, as the primary expressions of territorial shaping in the ancient world. Also, most of the symbolic shaping would have been inundated with cult and ritual, even more so than in modern times, adding the weight of divine authority to the idea of the 'region', i.e. polis. This perception is important in understanding the role of the institutions, particularly the priests, but

22 Kamphorst (forthcoming) addresses terms of connectivity in inter-state relations.

23 Paasi (2009), see above Chapter 2. 
also the wider community who 'performed the region', ${ }^{24}$ as actors who in principal were following the divine will. With these few details in mind, the model of regional identity would also prove useful in studies of the ancient city in general that focus on similar issues of territory, social composition and institutions, and symbolic focus.

\section{Assessing the Framework of Analysis}

The bulk of this book has been channeled through the lens of the framework of analysis, developed in the second chapter (Table 2.2). Perhaps one of the principal assets of this study, this framework provides a tool through which the many changes in the evolving relationship between a shrine and a community can be weighed, analyzed, and compared in all their diversity.

Regarding the historical development, the case studies revealed that each relation between a city and an outlying sanctuary was a unique combination. This was particularly evident in the analyses of just the two cities and their fundamentally different paths of connecting to the major sanctuaries drawn into their orbit. Each shrine initially had a different radius, from local to regional, demanding unique strategies to incorporate them into the civic sphere. This was perhaps most evident with Stratonikeia and the different approaches applied towards Lagina and Panamara as the scope of each was realigned towards the urban community. Inseparable from the chronology of both city and shrine is the role of the environment - the physical and social geography that constituted the foundation of the nature and impact of the cult, if not its essence. The potential relevance of frontiers has already been discussed, but the landscape itself played an important role. The timelessness of the eroding slopes near Labraunda along with the strategic location near a passage and panoramic view over the plain below surely demanded a cult for a primordial and supreme deity. The power of place and cult was neither lost on the dynasty that came to rule nor the nearby city left behind in its wake. Social geography is equally significant. Proximity to local communities and accessibility to road networks may help explain the attraction of Lagina, but for the shrine of Sinuri this is less obvious and leads us to search for alternative explanations, such as its embeddedness in the productive landscape. The rapidly disappearing cultural landscape around Panamara will leave many questions unanswered, but the hilltop shrine would in any case have acted as 
a beacon of urban presence for a region otherwise visually separated from the city. Landscape has an agency of its own in this equation.

The topochronic conditions of shrine and city constitute the foundational layers of their connection, but the shape that this takes is as varied. In assessing the degree of integration of a shrine into the urban sphere, a variety of factors need to be considered individually, before they can be lumped together. One of the most obvious is the physical appearance of the place of cult, the monumental and ritual space. In a quick assessment, one might think that if it looks and acts like a civic sanctuary, then it must be one too. All of the cases here present as such, but a closer investigation shows a marked deviation in intent early on. With the possible exception of Lagina (initially under the aegis of Koranza), monumentalization processes at these shrines were well underway, if not largely completed, prior to the advent of the city. Labraunda was a dynastic showcase that remained one even under Mylasa, while the shrine of Sinuri never became a polis shrine, although the resemblance was strong. Panamara blossomed under Stratonikeia, but its monumentalization began early on as an investment by local communities. Concentric ritual space, so conducive to community-forming as discussed above, was articulated at all of the shrines and this capacity would have been another major asset. Linear space, on the other hand, is in most cases visible with the advent of the polis through the use of processions that connected city and shrine.

Ritual performance is another critical indicator of change that allows us to observe the shift in cultic scope in perhaps even higher resolution, depending on the survival of the sources. The crowds that the shrines drew may be evidenced by increasing water supplies, as at Labraunda and Lagina, ceramics such as tableware or terracottas (although most of this has not been published), but especially inscriptions. Festivals provided a joint focus of attention for the newly incorporated communities and are seen to be increasingly scripted events, particularly at Lagina and Panamara. The element of spectacle was equally on the rise and, besides the sacrifices and singing, collective rituals such as banqueting and especially contests would have sharpened the sense of 'community spirit', even though these rituals were simultaneously used to define and label the various segments of the population. The changes in ritual performance would have been gradual and tailored to each situation.

Sanctuaries in Asia Minor have long been studied with an eye towards their economies, the nature of their priesthoods, and their degree of autonomy. The legal administration and organization of these religious centers, primarily informed in the present cases by epigraphic evidence, is an important barometer of change. Change is evident at all of the cases analyzed in this study, but 
is perhaps the most poignant at Labraunda, which for a time was contested space between the priests and the polis, at odds over administrative control of the resources of the shrine. Economy is certainly an important factor and is especially apparent in the landscape of Mylasa, where a construction allowing for private lands to pass to the sanctuary, only to be leased back to the original owners for further exploitation, originated in the third century. This is another sign that each city devised its own strategy concerning the administration of its shrines, and that this also developed over time. Especially interesting are the fluctuations observed in the local communities who are attached to the sanctuary. While this is best visible with the syngeneiai at the shrine of Sinuri, the other sanctuaries in this study also had communities of their own, e.g. the Korrides syngeneia at Labraunda, or the katoikountes at Lagina; interestingly, the least is known of a residing community at Panamara after the passing of the koinon of the Panamareis.

Cult and festival were clearly instrumental in the urban mediatization strategies of the polis. Mylasa clung to the image of Zeus Labraundos as established by the Hekatomnids while using the grand shrine as civic podium. Besides resetting the scope and focus of the cult onto the city, the incorporated deity could also be used to establish geopolitical connections with peer communities or other powers of authority. Epiphanies were an important precedent as they were used to demonstrate the importance and relevance of the city on the political map. At Lagina an epiphany of Hekate accelerated Stratonikeia's claims of loyalty to Rome that eventually led to an extension of territory and especially the privileged recognition of asylia for the shrine. This in turn gave the polis reason to host a festival and petition for recognition and participation from its peer cities. The gods of these country sanctuaries increasingly appeared on the coinage of the cities, one of a variety of avenues that realigned the cults to their new communities.

This framework provides a lens to examine the many different ways that a sanctuary and its cult could become attached to a community. The outcome may or may not be surprising, but the main merit is three-fold. In the first place, it provides a means for identifying explicit areas of change, allowing us to move beyond a general impression that the available data gives. In the second place, the framework takes into account a wide variety of data, more than can probably be addressed in any one case. But this forces us to integrate the variety of sources and to look across the gaps in data and beyond a single data type. Finally, the structured approach allows for at least a degree of comparative analyses across different sanctuaries, despite the widely differing circumstances. This can help us understand the repertoire of options that cities had, 
leading towards a better understanding of why such sanctuaries were critical to developing cities and how such relationships were forged and maintained. Through this lens we can gain clearer insight into the strategies deployed by developing urban communities as they sought to position themselves and anchor their identity in a world outlined by warfare and local rivalries, but also one with increasing paths of connectivity. Rather than providing a monolithic model, this framework, with its integration of data and structural approach, can expose the wide diversity of solutions, which should lead to new questions in turn.

\section{Final Remarks}

This book began with a description of the shrine of Labraunda and the example of the power of its landscape, asking the question of who it belonged to. As we have seen, the answer is complex and depends on one's perspective in time and place. This may be said of Karia in general, but it may also be said of developing relationships between sanctuaries and cities across Asia Minor in the Hellenistic era, particularly in the later third and second centuries BC. At a time when local lines of organization were being blurred or erased, communities were blending together or being torn apart, and power alliances were constantly shifting, sanctuaries offered a haven of stability and local divine authority, at least on the surface. This is surely a major factor behind the surge in poliad deities that cities begin identify themselves more and more with, a phenomenon designated by Andrew Meadows as the 'Great Transformation.' ${ }^{25}$ The realignment of the scope of local or regional sanctuaries to first include the rising city, sometimes even including a revival of cult, then to solidify the bond, and finally to present it as the will of the gods is no small feat. Continuity of sacred landscapes would need to be stressed all the more as they merged with civic territory, making the presence of the new community appear natural and divinely sanctioned. The logic behind the surge of local and regional sanctuaries being absorbed by rising cities, as shown at the beginning of this book, now seems clear.

Current models address the role of outlying sanctuaries in the Archaic and Classical Greek world in the context of the rise of the polis, but omit Asia Minor or the second rise of the polis in the Hellenistic era. Studies of sanctuaries in Asia Minor have, in turn, focused on their economy and autonomy, but

25 Meadows (2018), a phenomenon which he observes through the increasing portrayal of deities on civic coinage in the second century вс. 
omit their relation to landscape. Both models are driven by disciplinary focus, but lack the holistic approach needed to address the multifarious situation in Asia Minor. And so, a framework of analysis was developed. Informed by a variety of theories, models, and various approaches, the framework provides an approach to these many different sanctuaries and their contexts which is both systematic and yet not too rigid in that it allows for their diversity to become apparent. A handful of case studies were selected that could yield sufficient data to intensively test the framework and allow for comparative analyses of the results. The fruitfulness of this overall and combined approach was demonstrated above. It was shown that these relationships could develop in many ways, with many different manifestations. Each combination of city and sanctuary was unique, yet despite their many differences, a number of recurring concerns emerged - especially social cohesion and the need for external recognition as cities sought to put themselves on the larger map. This study has exposed some strategies that were developed to address these concerns, and it has made clear that sanctuaries such as those examined here were linchpins in this process.

\subsection{Suggestions for Further Research}

A number of issues were raised in the preceding pages, opening up areas of inquiry that deserve further exploration. In the first place a further application of the framework of analysis from this study would help examine the relationships between other expanding poleis and their country sanctuaries, such as those shown in the introduction (Table 1.1). This framework could on the one hand provide interpretations for cities and sanctuaries in analogous situations, such as Pisidian Antioch and the sanctuary of Men Askaenos, or Aizanoi and the sanctuary of Meter Steunene. It could also help with tentative interpretations for sanctuaries whose data sets are much more restricted, such as the sanctuaries in the chora of Myra, or the sanctuary of Zeus Stratios near Amaseia. It might even be of help with sanctuaries whose locations are as of yet unknown - one of the most prominent examples is the extramural Nikephorion of Pergamon, but also the temple of Artemis Pergaia, somewhere outside of Perge - of course the section on geographical data would remain empty but other areas could still be indicative of the role that the sanctuary fulfilled for the polis. With some adaptations it could also help understand the relationship between federation sanctuaries and the poleis which 'hosted' them, such as the Letoon, home of the Lykian League, and Xanthos. This framework of analysis is meant to be dynamic; studies at other sanctuaries and poleis may well lead to very other conclusions, and in any event to a modification of this framework, based on the situation at hand. 
The visual regions of a sanctuary were discussed as an important factor for their being drawn in to the orbit of the polis, as their panoramas were merged with the view from the city, literally expanding its horizons. In this respect a more comprehensive visual analysis of sanctuary viewsheds would be worthwhile, to investigate how these may have been related to their overall function. ${ }^{26}$ Viewshed analysis could be an important research tool for addressing questions such as whether viewshed shapes correspond to particular types of sanctuaries, or whether viewshed size is a valid indicator of a sanctuary's relevance for the polis. Visual studies should also be further incorporated in studies that address polis religion, but also studies that explore other kinds of sensory perception for a holistic approach to understanding how these places and their festivals functioned.

Polis religion, now being reassessed through numerous angles, ${ }^{27}$ should also be viewed through an Anatolian lens. This present study has revealed alternative views on how state cult, or polis religion, may have been interpreted in Karia. At the same time, the function of sanctuaries in integrating heterogeneous societies could be brought into sharper relief through comparative studies with colonization processes in Magna Graecia or the Black Sea region. This could also impact views on Hellenization in general, and at least on the mediatory role of sanctuaries and the porosity of frontiers.

While addressing the indicators of urban involvement in this research, several very different areas pertaining to sanctuaries were explored, such as priesthoods, processions, and ritual performances. A number of studies examine these as institutions in closer detail. ${ }^{28}$ But a deeper analysis of the social composition of the polis and understanding how this was expressed, or at least projected, during the urban festivals of these sanctuaries would certainly enhance our appreciation of the role these sanctuaries had in consolidating community; such analyses might also show the impact of class differentiation, the mechanisms of power, and channels of resistance, and the many voices that invested layers of identity and pride at the shrine. At the same time, a closer examination of communities residing in local settlements at or near country sanctuaries would greatly increase our understanding of their social function. These approaches would surely lead to important refinements of the framework while embedding this relationship in the context of the wider academic discourse on these social and economic topics.

\footnotetext{
26 Williamson (2014b), for a start.

27 Kindt (2012); Eidinow (2015); Eidinow et al. (2016); Mikalson (2016).

28 On priesthoods: Dignas (2002a) and (2002b), Dignas and Trampedach (2008); Horster and Klöckner (2011), and Richardson and Santangelo (2011); and Chaniotis on processions and festivals: e.g. Chaniotis (1995), (2003), (2006b), (2010), (2013).
} 
Cult networks were a central part of the discourse of this study, but these could be subjected to much more detailed network analysis to discover their topologies and reveal patterns of interest, especially concerning aspects of reciprocity. This would include analyzing the weights of nodes, and whether their ties are weak or strong. It might also lead to 'shortest path' connections between poleis via sanctuaries, especially when situated in a geographic information system, with least-cost path analysis, and navigational routes by land or by sea, in combination with seasonal data. Agent-based modelling can also complement insufficient data, with intensive and 'random' simulations that provide material for pattern analysis. This has the potential to reveal local, regional, or even 'global' inter-polis festival circuits. Connected to this should be a study of the other kinds of exchanges that may have taken place between these cities, e.g. not just trade, but perhaps the extension of citizenship to certain foreigners (proxeny), or inter-state treaties (such as sympoliteia). Studying festivals through this lens may very well prove them to have been the glue of international Hellenistic society, and one of the prime facilities through which the global political culture was developed. ${ }^{29}$

Finally, much more archaeology is needed to adequately address the issue of the political and social impact of country sanctuaries in Asia Minor. I have tried as far as possible to indicate the local contexts of sanctuaries, particularly with regard to the locations and nature of their local settlements. But these have hardly been the object of research until now. The last suggestion for further research, with which I will close this work, focuses on understanding the sacred landscapes of these sanctuaries, and of the poleis, in a much higher resolution than is now available. This will entail not only more literary and epigraphic studies, but especially archaeological surveys which will help place the sanctuary in its own social context, including not only the local settlement of the sanctuary, but also other nearby settlements, shrines, necropoleis, but even farmsteads or other kinds of activity. Only through this high resolution can it be determined what the 'spatial continuum' around a sanctuary was actually like. ${ }^{30}$

In short, the results have been promising so far and the framework has proven its worth, highlighting the areas of the greatest change and continuity for cult and community as urban rituals were etched onto sacred landscapes. But much remains to be done.

\footnotetext{
29 Van Nijf (2012); van Nijf and Williamson (2014); (2015); (2016). See also the doctoral research of Sjoukje Kamphorst, University of Groningen, on inscriptions of connectivity. 